\title{
FIRE BLIGHT OF PEAR IN EGYPT: CHRONOLOGICAL BACKGROUND AND NEW FINDINGS
}

\author{
NAGLAA M. BALABEL; N. S. FARAG; \\ T. A. EL-SHARKAWY; FATEN S. MANSOUR
}

Plant Pathology Research Institute, Agric. Res. Center

Corresponding Author: Nabil S. Farag, E-mail: nsobifarag@yahoo.com

(Manuscript received 26 August 2018)

\begin{abstract}
$\mathrm{T}$ he pear disorder described as fire blight has long been disputed in Egypt due to relatively dry climate unfavorable for the disease epidemic. Efforts were carried out in the present work to clarify the cause of confusion and to elucidate some aspects of such discrepancies. Orchards inspections in ElBehera governorate revealed obvious scorching on foliage of some trees, without noticeable seeping under many circumstances. The syndrome disputed plant pathologists in many institutions, because of the validated absence of such scorching on apple trees raised in the same pear orchard. Samples collected from different pear organs of sporadically affected trees, were subject to isolate the pathogen on either high sucrose or Miller- Schroth (MS), media selective for Erwinia amylovora. Macroscopic, microscopic, biochemical and molecular determinations revealed no obvious variation among isolates recovered from different pear tree organs. The obtained results indicated that, the isolated bacteria belonged to Erwinia amylovora. Isolates from cankerous branches, however, were more pathogenic compared to those recovered from other plant organs. The rootstocks dominating in Egypt are P.communis, P.betulaefolia and P.calleryana. The effect of such rootstocks on" MKM" grafted pear cultivar was compared. The differences in the blooming date and variation in the occurrence and severity of such a disorder was evaluated. The earlier blooming, as shown influenced by the rootstock effect, the lower the disease expression. P.calleryana and P.betulaefolia showed full blooming in the third week of March, and escaped severe infection. The remarkable late onset of flowering of P.communis grafted trees commencing at the end of March, resulted in greater disease complications, due to the possible discharge of bacteria from holdover cankers, coinciding with more favorable temperature and higher insect activity. The influence of different rootstocks on growth habits of pear grafts and their respective influence on the disorders in concern must be fully investigated. The occurrence of associated microscopic mites must be seriously considered, which may be contributing to the reported discrepancy among scientists and the contradictory remarks on fire blight epidemics in Egypt.

Key words: Erwinia amylovora , P.communis, P.betulaefolia P.calleryana, different rootstocks, pear organs and eriophyde mites .
\end{abstract}




\section{INTRODUCTION}

The disease of fire blight was first mentioned in Egypt in 1962 (El-Helaly et al. 1964) then many scientists reported spreading of the disease in some governorates (Tawfik et al., 2006; and Shoeib et al.,2017). Early in April 1982 and 1983 symptoms similar to fire blight, blossom and twig blast of pear have ravaged orchards at certain districts in northern Egypt. The conditions necessary for fire blight outbreaks, especially rains, are not prevailing for the disease epidemic though the record made by El-Helaly et al. (1964). It is worth noting, however, that such record was made many years ahead of Germany with extremely favourable climatological conditions for outbreaks (Van der Zwet and Keil, 1979). That record has contradicted the basic principles of fire blight epidemics in general and caused a lot of confusions in particular.

Monitoring affected orchards at different governorates in Egypt revealed inconsistent occurrence of scorching in juvenile parts of the tree but lacking distinct ooze droplets of bacteria, characterizing fire blight. Sporadic cankerous pear trees adjacent side by side to young apple trees in the same orchards were found free from any disorder (Farag et al., 1986). Similar observations were reported by Paulus(1983) and Van der Zwet (1983). The absence of ooze in cankerous branches and trunks was also reported by El-Goorani (1973) and Paulus(1983). In literature, the bacterial ooze on blasted pear buds is associated with Erwinia amylovora and absence of ooze has been one of the features differentiating Pseudomonas syringae infection. However, production of ooze by an unidentified species of Pseudomonas on Magness pear blossoms and buds was reported by Van der Zwet and Keil (1979). Another species was described in Russia as P.syringae, causing a disease which differed from fire blight and blast in that the bark cracks and peels off, with no infection on unripe fruits.

Blossom blight phase of fire blight is crucial in rosaceous plant, namely apple and pear trees. Control trials with chemicals in Egypt over the last three decades did not overcome the problem, though worldwide reports concluded that copper fungicides can suppress the disease (Paulin and Lachuad, 1984). Different brands of agrostreptomycin did not show any noticeable control in Egypt and sporadic annual increasing syndromes are still occurring. Spraying dithiocarbamic acid fungicide derivatives, namely mancozeb, gave promising control on yearly application. Freedom of fungal infection in affected samples was almost common (Farag, unpublished Data).

The brief account outlined above, revealed the necessity of studying the existing dilemma from another view point. 
The objective of this work was to define some factors contributing to the problem, which started in 1964 and exaggerated in1983, as fire blight. The effect of pear rootstocks on the date of blooming in relation to the disorder the involvement of bark borers and eriophyde mites were considered.

\section{MATERIALS AND METHODS}

\section{1- Pear orchards and sampling:}

Four pear orchards at Kafr El-Dawar, El-Behera governorate, were subjected to seasonal examination for two years starting 2015. Observations on orchard condition were recorded with special emphasis on the age of the trees and the root-stock used and certain growth parameters.

Reasonable samples of blighted blossoms, leaves, and thin sections of cankerous branches were collected for laboratory examination and isolation. Surface sterilization was avoided because of the tenderness of samples and highly selective media for isolation of Erwinia amylovora were used. Miller-Schroth (MS) medium (Miller and Schroth, 1972) and high sucrose medium (Cross and Goodman, 1973) were principally used for isolation. Single colonies were selected and propagated on King's B slants.

Bacterial stock suspension in sterilized tap water was kept during the course of the study.

\section{2- Pathogenic potential of isolates:}

Bacteria recovered from stems, shoots, leaves, blossoms and fruits sample were tested for pathogenicity on green immature pear fruitlets. Immature pear fruitlets were punctured with a sterile needle laden with the bacteria isolated from different pear organs.

Five replicate fruitlets were considered for each isolate along with control treatment (sterile water). Re-isolation was also made from inoculated fruitlets on King's B medium.

Pathogenic potential of isolates on inoculated fruitlets was determined based on the extent of necrotic lesion, or the diameter of greasing area and oozing according to Westwood (1978) scale as follows:

\begin{tabular}{|c|c|c|}
\hline 0 & $=$ & no necrosis and no oozing \\
\hline 1 & $=$ & slight necrosis and oozing \\
\hline 2 & $=$ & moderate necrosis and oozing \\
\hline 3 & $=$ & big necrosis and oozing \\
\hline 4 & $=$ & extraordinary necrosis and oozing \\
\hline 5 & $=$ & blackening necrosis and oozing \\
\hline
\end{tabular}




\section{3- Disease assessment:}

On farm determination of the disease spread was made by the end of April in the years of experimentation. The number of diseased clusters along four branches / tree was enumerated. The total number of affected clusters was counted in five labeled trees and rationed to the total number of clusters.

\section{4- Identification of the pathogen:}

Pathogenic isolates were bacteriologically identified according to Krieg et al. (1994). Phenotypic characteristics of colonies and other microscopic examination were described.

\section{5- Polymerase chain reaction (PCR):}

Confirmative identification of isolated bacteria was made with PCR and affiliation technique. The isolates were grown in $10 \mathrm{ml}$ of nutrient broth for 48 hours, centrifuged, resuspended, diluted in water and added to the reaction mixture (described below). For DNA extraction, the bacteria were lysed by lysozyme and sodium dodecyl sulfate, and the liberated nucleic acids were purified by repeated extraction with phenol and then with chloroform-isoamyl alcohol. Five micro liters of the diluted DNA preparation was used for the PCR protocol suggested by Bereswill et al. (1992).

Two oligonucleotide primers from the borders of the pEA29 fragment with the sequences of:

5'-CGG 'TTT TT'A ACG CTG GG for primer A

5'-GGG CAA ATA CTC GGA TT for primer B

were used as described by Bereswill et al. (1992). PCR amplification was carried out in a total volume of $50 \mu$ with the following composition:

\begin{tabular}{|l|l|l|l|}
\hline & Working concentration & $\begin{array}{l}\text { Volume per reaction } \\
(\mu \mathrm{l})\end{array}$ & Final concentration \\
\hline Molecular - grade water & & 34.80 & \\
\hline PCR buffer & $10 \mathrm{x}$ & 5.00 & $1 \mathrm{x}$ \\
\hline $\mathrm{MgCl} 2$ & $50 \mathrm{mM}$ & 3.00 & $3 \mathrm{Mm}$ \\
\hline $\mathrm{dNTPs}$ & $10 \mathrm{mM}$ & 1.00 & $0.2 \mathrm{mM}$ of each dNTPs \\
\hline Primer A & $10 \mu \mathrm{M}$ & 0.5 & $0.1 \mathrm{Mm}$ \\
\hline Primer B & $10 \mu \mathrm{M}$ & 0.5 & $0.1 \mathrm{Mm}$ \\
\hline Taq polymerase & $5 \mathrm{U} \mu \mathrm{L}-1$ & 0.2 & $1 \mathrm{u}$ \\
\hline Subtotal & & 45.00 & \\
\hline DNA & & 5.00 & \\
\hline $\begin{array}{l}\text { Total reaction volume of a } \\
\text { single PCR reaction }\end{array}$ & & 50.00 & \\
\hline
\end{tabular}

PCR cycling programme was run in the following sequence:

$5 \mathrm{~min}$ at $93^{\circ} \mathrm{C}, 40 \mathrm{cycles}$ of $30 \mathrm{~s}$ at $93^{\circ} \mathrm{C}, 30 \mathrm{~s}$ at $52^{\circ} \mathrm{C}$ and $1 \mathrm{~min} 5 \mathrm{~s}$ at $72^{\circ} \mathrm{C}$ and a final step of $10 \mathrm{~min}$ at $72^{\circ} \mathrm{C}$. The PCR products were separated on a $1.5 \%$ agarose gel (1.5 to $2 \mathrm{~h}$ at $100 \mathrm{~V})$, stained with ethidium bromide $\left(0.5 \% \mu \mathrm{gL}^{-1}\right)$, and visualized with ultraviolet light. 


\section{6- Growth variables of pear trees:}

Observations were made in four selected orchards in 2015and 2016. Selection of orchards was made according to the age (8-10 years old) and root-stocks used. The dominant root stocks were Pyrus communis, P. betulaefolia and P.calleryana grafted with "MKM" scion cultivar were considered. Five trees in each orchard of approximately equal size were marked and weekly visited starting at the time of blooming onset for one month. Complete flowering were carefully determined as well as the date of apparent fruit setting to compare the effect of different root- stocks on such characters.

\section{7- Statistical analyses:}

Statistical analyses were preformed and also date of pear blooming was made. The effect of pear rootstocks on fire blight sporadic infection was compared according to Duncan (1955).

The Post - hoc (LSD 0.05) using SPSS 17 was used to determine the difference in pathogenic potential of isolates recovered from different pear organs.

\section{RESULTS}

\section{Preliminary identification:}

No variation in morphological, physiological and biochemical characteristics could be recognized in the most pathogenic isolate in each group in concern subject to tentative identification.

All isolates were short - rods, non spore former, gram negative, motile rods. All isolates were able to utilize $L(+)$ arabinose, fructose, galactose, trehalose, mannitol glucose and sorbitol as carbon source. Meanwhile, these isolates were not able to utilize D (-) arabinose, cellobiose, lactose, maltose, mannose, xylose as carbon source. Other characteristics are shown in Tables (1) and (2).

Table 1. Utilization of different carbohydrate by isolated bacteria from different pear organs.

Compound
L (+) arabinose
D (-) arabinose
Cellobiose
Fructose
Galactose
Glucose
Lactose
Maltose
Mannose
Sucrose
Xylose
Mannitol
Sorbitol
Salicin

\begin{tabular}{ccc} 
& & \multicolumn{2}{c}{ Isolate source } \\
Stem & Shoot & Leaf \\
+ & + & + \\
- & - & - \\
- & - & - \\
++ & ++ & ++ \\
++ & ++ & ++ \\
++ & ++ & ++ \\
- & - & - \\
- & - & - \\
- & - & - \\
++ & ++ & ++ \\
- & - & - \\
++ & ++ & ++ \\
++ & ++ & ++ \\
- & - & -
\end{tabular}

Blossom
+
-
-
++
++
++
-
-
-
++
-
++
++
-

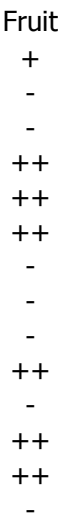

* The reaction determined after 7 days of incubation

- Negative reaction + Moderate acidity $\quad++$ High acidity 
Table 2. Biochemical and physiological characteristics of isolated bacteria from different pear organs.

Test

\begin{tabular}{cccc}
\multicolumn{5}{c}{ Isolate source } \\
Stem Shoot $\quad$ Leaf Blossom Fruit
\end{tabular}

$\mathrm{KOH} 3 \%$

Catalase

Oxidase

Urease production

Starch hydrolysis

Gelatin liquefaction

Voges-Proskauer (VP)

Methyl red (MR)

Levan production

Nitrate reduction

Reducing substance from sucrose

$\mathrm{H}_{2} \mathrm{~S}$ from cysteine

Fluorescent pigment *

Pink pigment**

* On King's B medium (KB)

** On yeast extract-dextrose - $\mathrm{CaCO} 3$ (YDC) medium.

+ Positive reaction

- Negative reaction

Results reported in tables (1) and (2) indicated that the bacterial isolates recovered from different pear organs under study could be placed under Erwinia amylovora the causal of fire blight disease.

\section{Polymerase chain reaction (PCR) study:}

Polymerase Chain Reaction (PCR) was employed for further confirmation of identity of isolates as Erwinia amylovora. Universal primers A and B used in tested isolates to identify pE29 plasmid of Erwinia amylovora reacted positively and produced the expected $900 \mathrm{bp}$ product shown in Figure (1). The results agree with those obtained by other investigators. On the other hand, the results showed equal signal at $900 \mathrm{bp}$ for all isolates that indicate no variation between isolates obtained from different plant organs could be detected in PCR test. 


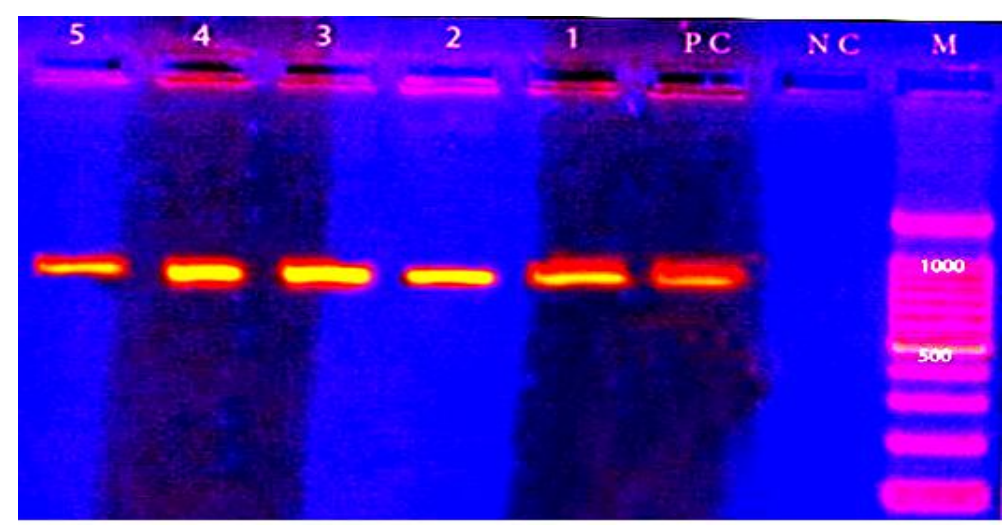

Fig., 1. Lanes 1:5, PCR product of (5) isolates of E. amylovora isolated from different pear organs using two oligonucleotide primers from the borders of the pEA29 fragment, 900-bp amplicon from E. amylovora $\mathrm{M}$, molecular size marker (100-bp DNA ladder; size(base pair)

Lane N.C, PCR negative control, Lane P.C, PCR positive control

\section{Pathogenicity and pathogenic potentials of isolates:}

Bacterial isolates propagated on King's B medium for 3 days at $28{ }^{\circ} \mathrm{C}$ were tested.

Results in table (3) showed that isolates from different sources were pathogenic. The most aggressive isolates, under the conditions of the experiment, were those isolated from stem holdover cankers and shoot cankers. Weak virulence was recognized for those recovered from leaves and fruits. Moderate severity, however, was shown for isolates recovered from blossom.

It is important to note that regardless of varied severity, as expressed by oozing from the site of inoculation the infection was started with greasing around the fruit puncture. The greater the diameter of greased area the greater the pathogenic potential could be recognized. Prolonged incubation of inoculated fruitlets resulted in relatively variable degrees of fruit blackening and shrinkage (fig., 2).

Table 3. Variation in pathogenic potential of isolates recovered from different pear

organs

\begin{tabular}{|c|c|c|c|}
\hline Origin of isolate & $\begin{array}{l}\% \text { of fruitlets } \\
\text { infection }\end{array}$ & $\%$ of oozing & $\begin{array}{c}\text { Severity of infection } \\
\text { (Mean } \pm \text { standard } \\
\text { error) }\end{array}$ \\
\hline Stem cankers & 100 & 80 & $88^{1} \pm 4.9$ \\
\hline Limb cankers & 100 & 80 & $84^{2} \pm 4.0$ \\
\hline Leave stalks & 100 & 40 & $64^{3} \pm 9.8$ \\
\hline Blossoms & 100 & 60 & $72^{4} \pm 4.9$ \\
\hline Fruits & 100 & 20 & $52^{5} \pm 4.9$ \\
\hline \multicolumn{4}{|l|}{$\mathrm{LSD}=0.05$} \\
\hline \multicolumn{4}{|c|}{ Values are Means $\pm \mathrm{SE}_{,}{ }^{1,3} P=0.01,{ }^{1,4} P=0.08,{ }^{1,5} p<0.001,{ }^{2,3} P=0.03,{ }^{2,5} P=0.001,{ }^{4,5} P=0.03$} \\
\hline
\end{tabular}




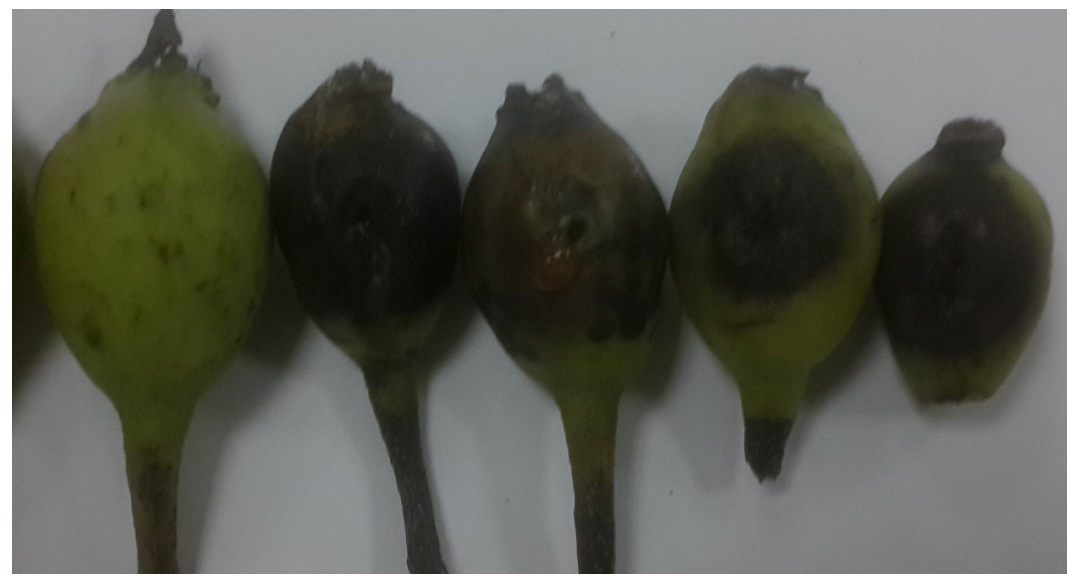

Fig. 2. Immature pear fruitlets showing blackened area with droplet of bacterial ooze after inoculation with E. amylovora and immature pear fruitlet inoculated by sterile distilled water as a negative control (for left).

\section{Fire blight in orchard grown pears:}

The four orchards selected in Behera governorate representing different pear rootstocks were examined in the fruiting seasons 2015 and 2016. Data presented in Table (4) showed that the sporadic occurrence of fire blight, at the orchard level, varied with the rootstock grafted. However, the disease incidence in the year 2015 was slightly higher than that recorded in 2016. The root stocks generally used in the four orchards, displayed significant differences in the percentage of infection being higher for P.communis. However, P.betulaefolia and P.calleryana were significantly more tolerant to the disease without any statistical differences between them. The data presented in Table (4) are the percentages of damaged spurs per tree. The percentage of affected trees was neglected because of the rarity of the event on both P.betulaefolia and P.calleryana.

Table 4. Effect of pear rootstocks on fire blight infection during 2015 and 2016.

\begin{tabular}{|l|c|c|}
\hline \multirow{2}{*}{ Rootstock } & \multicolumn{2}{|c|}{ (natural pear rootstock) infection \% } \\
\cline { 2 - 3 } & Season $2015^{*}$ & Season $2016^{*}$ \\
\hline P. communis & $37.0^{\mathrm{b}}$ & $35.0^{\mathrm{b}}$ \\
\hline P.betulaefolia & $22.3^{\mathrm{a}}$ & $22.0^{\mathrm{a}}$ \\
\hline P.calleryana & $23.0^{\mathrm{a}}$ & $22.3 \mathrm{a}$ \\
\hline
\end{tabular}

*means of four orchards

Means having the same letter at the same column are not significantly different $(p<0.05)$.

\section{Date of flowering in relation disease incidence:}

Data in Table (5) showed that, rootstocks varied as to the date of blooming in the years of study. The late blooming with $P$. communis rootstock was commenced on $20^{\text {th }}$ and $23^{\text {th }}$ of March in 2015 and 2016, respectively. The 
corresponding blooming dates for P.calleryana in 2015 and 2016 were $17^{\text {th }}$ and $10^{\text {th }}$ of March as well for P.betulaefolia. Such slight differences in blooming onset may not explain the differences in severity percent. The completed full blooming may explain differences expressed by severity.

It is worth noting, however, that a complete fruit set was recognized by mid April, 2015 though sporadic spared inflorescence was noticed, for P.calleryana and $P$. betulaefolia. Meanwhile, blooming was continuously active in $P$. communis with low fruit setting, reaching full fruit setting by April $30^{\text {th }}$.

No significant differences were noticed in disease severity with P.calleryana and P.betulaefolia rootstocks in both seasons; however, significantly higher severities were experienced with $P$. communis rootstocks.

Table 5. Date of blooming of pears on different rootstocks and severity of fire blight.

\begin{tabular}{|l|c|c|c|c|c|c|}
\hline \multirow{2}{*}{ Rootstock } & \multicolumn{2}{|c|}{ Flowering } & \multicolumn{2}{c|}{ Full fruit set } & \multicolumn{2}{c|}{ Severity\% } \\
\cline { 2 - 7 } & 2015 & 2016 & 2015 & 2016 & 2015 & 2016 \\
\hline P.betulaefolia* & $17^{\text {th }}$ mar. & $18^{\text {th }}$ mar. & $15^{\text {th }}$ ap. & $17^{\text {th }}$ ap. & $26.3^{\text {a }}$ & $28.0^{\text {a }}$ \\
\hline P.calleryana* & $17^{\text {th }}$ mar. & $10^{\text {th }}$ mar. & $15^{\text {th }}$ ap. & $12^{\text {th }}$ ap. & $23.0^{\mathrm{a}}$ & $26.3^{\text {a }}$ \\
\hline P. communis** & $20^{\text {th }}$ mar. & $23^{\text {th }}$ mar. & $30^{\text {th }}$ ap. & $30^{\text {th }}$ ap. & $37.0^{\mathrm{b}}$ & $35.0^{\text {b }}$ \\
\hline
\end{tabular}

Means having the same letter in each column are not significantly different at 0.05

*Sporadic late inflorescence * * Continued blooming

\section{DISCUSSION}

Fire blight dilemma has long been disputed in Egypt since the first description made by El - Helaly et al. (1964). The conditions necessary for fire blight outbreaks, are not prevailing in Egypt and such an early record has been made many years ahead of Germany with better climatological conditions for disease predisposition.

From the bacteriological point of view, the early description of the so called "Egyptian isolates" of E. amylovora made by EL-Helaly et al. (1964) was skeptic and erratic to a large extent. They found that their isolates utilized glucose with acid production but not dextrose. Such specificity for different synonyms of the same substance is not known for E. amylovora. Moreover, they found that $5 \%$ sucrose with gelatin medium decreased the time of liquefaction from 15 to 4 days, which is contrary to what is known about protein sparing action of carbohydrate. Such discrepancies in the identification of the so called "Egyptian isolates of E. amylovora" along with the limited occurrence of diagnostic symptoms are looked upon with great concern. However, Abo EL-Dahab et al. (1983) reported on "Severe outbreaks of fire blight in Egypt during 1982-1983" and referred to the previous record of EL-Helaly et 
al. (1964). Meanwhile, EL-Goorani (1973) failed to isolate any pathogenic bacteria during a monitoring study extending over six years period.

Monitoring affected orchards in previous preliminary study at different governorates revealed inconsistent spread of scorching of juvenile parts of the tree resembling those of fire blight syndrome but lacking bacterial ooze droplets which is very characteristic of the disease. Sporadic and very few trees at orchard level were seen with dry marks of sap around the holdover cankers, in neglected uncarefully managed orchards. Apple trees raised in the same pear orchards near Alexandria did not show neither scorching nor ooze. Insecticides of certain groups especially those containing sulphur derivatives showed distinctly notable management effect in the subsequent years. Some growers, however, cleared their orchards and tried other crops, under the notion of fire blight.

The brief account outlined above reveals the necessity of managing the problem through considering other possible factors. Thus, the effect of pear root stocks dominating in Egypt on the suspected syndrome occurrence was postulated. Monitoring of previously listed affected orchards was considered and four of them with different root-stocks were selected.

Isolation of bacteria was made at pear blooming period on selective media and tested for pathogenicity in pear fruitlets and pathogenic potential of isolates from different organs was compared. Hold-over cankers were the most important source of primary inoculum for blossom infection in the spring as evidenced by the higher severity of infection (Beer and Norelli, 1977). The least severity was found for fruit isolates. The variation in severity or aggressiveness of pathogenic bacteria from different sources was previously noted in Ralstonia solanacearum (Balabel et al., 2005).

Identification of recovered bacteria was made according to Krieg et al. (1994) and further confirmed by PCR for five selected isolates using specific primers. Many phytopathogenic bacteria carry plasmids. However, in the case of Erwinia amylovora, a low copy number plasmid pE 29 has been shown in all isolates studied and responsible for modulates development of fire blight symptoms. This plasmid seems to play an important role in pathogenicity (Falkenstein, 1989). The presence of this plasmid in all isolates allowed primers specific to a DNA fragment of pE 29 for detection of Erwinia amylovora by PCR to be proposed (Bereswill et al., 1992) which were used in this study. All tests carried out revealed affiliation of all isolatcs shedied to E. amylovora

In the present study, the influence of pear rootstocks on scion development was correlated with disease incidence. Pyrus betulaefolia grafted with "MKM" cultivar scion 
was more resistant to infection compared to other rootstocks. The rootstocks of P.callaryana ,however, is not appreciated in Egypt because of certain physiological disorders as lime induced chlorosis, regardless of the early blooming and low chilling requirements favorable for escaping the disease. In conclusion, the pear cultivars are known to vary greatly in their reaction to E.amylovora (Koski and Jacobi, 2013) and may complicate fire blight studies.

The rootstocks and their influence on the liability to infection with Eamylovora was justified in this work by the finding that late blooming of MKM-grafted P.communis coincided with greater infection, through florets and intense visits of pollinating insects because of warm temperatures in this period (Said and el- shall 1987). It is worth noting, however, that P.communis is the principal rootstock dominating in Egyptian orchards that might be the biggest contributor to such crucial discrepancy in and contradictory remarks on such dilemma. The warm conditions in April favor greater physiological activity of pear trees and greater flow of sap, along with possible bacterial discharge from holdover cankers. In this regard, Van der Zwet (1983) reported one Alexandrine pear tree showed remnant streaks along the bark surface that were attributed to bacterial ooze early in spring. In the same orchard he found few younger apple trees free from either blast or blight symptoms. Moreover, he added that such remnants streaks may be attributed to the limb borer insect Zeuzera pyrena, a major problem of pome trees in Egypt. The absence of ooze on cankerous branches and stems was also reported by EL-Goorani (1973) and Paulus (1983).

In the present work, however, only sporadic suspected trees with symptoms could be recognized in the orchards under investigation, and no outbreaks could be documented. Some investigators reported that, water plays an important role in the spread of fire blight. Rain disseminates primary inoculum within orchards from overwintering cankers to blossoms and young vegetative shoots (Van der Zwet, 1994). Therefore, the dry conditions and lack of rains at the time of blooming might be among the reasons for the absence of outbreaks in Egypt. Therefore, the conditions necessary for disease inception and expression and those required for an outbreak must not be confused. The pathogen is disseminated by insects, rain, wind or wind-driven rain to open blossoms, shoot and leaves, where infection may occur. The effect of rootstocks on plant characteristics in general and susceptibility to fire blight must be seriously considered, in a joint work between horticulturists and plant pathologists at the cellular and biochemical levels.

The aforementioned findings and previous observations did not explain the freedom of Apple trees in Egypt from such confusing syndromes, though planted in 
situ the same orchard. Historically, Apple is known as original host for fire blight outbreaks.

Accidentally, during microscopic lab examination of collected samples, the leaf petioles showed microscopic mites (40x). The occurrence of such individuals and their stages in almost all the samples examined may explain the discrepancies in finding of different investigators, and may provide a partial solution if deat with seriously.

In retrospect, the pear dilemma in Egypt could not be regarded as fire blight outbreaks. The pathogen $E$. amylovora definitely exists and may have been introduced to Egypt with imported rootstock seedlings as an inconspicuous latent infections, or through any other possible means (Van der Zwet and Beer, 1995) who reported that, rootstocks is an important phase of fire blight, however, they can play a substantial role in fire blight epidemiology (Deckers and schoofs, 2008).

Paulus (1983) found no evidence of fire blight in Egypt on mature trees and reported many causes contributing to the decline and the possibility of fire-blight must be seriously investigated. Van der Zwet (1983) attributed the decline to fire-blight, blast and severe insect damage. Farag et al. (1986) highlighted the pear disorder in Egypt and concluded the involvement of some insect borers along with a Pseudomonas strain that can infect Phaseolus vulgaris. El-Goorani (1973) after many years of the first record made in 1964 reported the failure to isolate any pathogenic bacteria during a monitoring study extending over a six -years period. Farag (1993) reported a lot of pitfalls in fire blight diagnosis made in both Egypt and abroad.

Finally, it is worth noting to emphasize that different control measures and spraying antibiotics did not show any promising effect. However, dithiocarbamates fungicides as Mancozeb gave very promising control after limited application at the time of blooming (Farag unpublished data). Intensive acarological studies must be seriously considered. A declaration of Egypt's freedom from fire blight epidemics became an urgent need. Emphasis on occurrence of sporadic and very limited cases of blighted trees should be made to eliminate confusion with exact meaning of outbreaks that requires specific conditions namely rains, temperature and those for pathogenesis. It is very important to differentiate between conditions necessary for disease inception and those necessary for outbreaks. Further investigations are definitely recommended, to help and define an integrated program dealing with the disorder and to avoid any further confusion as well as reach an unequivocal conclusion with respect to the real status of fire blight outbreaks in Egypt., where conducive environmental conditions are Mostly absent. 


\section{REFERENCES}

1. Abo-El-Dahab, M.K., M.A. El-Goorani, H.M.El- Kasheir, and Alia A. Shoeib.1983. Severe outbreaks of pear fire blight in Egypt. Phytopath. Medit., 22: 168-170.

2. Balabel, Naglaa.M., Wedad.E. Eweda, M.I. Mostafa and N.S. Farag. 2005. Some epidemiological aspects of Ralstonia solanacearum. Egypt.J.Agric.Res., 83(4): 1547- 1564.

3. Beer, S.V. and J.L. Norelli. 1977. Fire blight epidemiology: factors affecting release of Erwinia amylovora by cankers. Phytopathology, 67: 1119-1125.

4. Bereswill, S., A. Pahl, P. Bellemann, W. Zeller, and K. Geider.1992. Sensitive and species specific detection of Erwinia amylovora by polymerase chain reaction analysis. Applied and Environmental Biology, 58: 3522-3526.

5. Crosse, J.E. and R.N. Goodman.1973. A selective medium for a definitive colony characterististics of Erwinia amylovora. Phytopathology, 63:1425-1426.

6. Deckers, T. and H. Schoofs.2008. Status of the pear production in Europe. Acta Hortic., 800:95-105.

7. Duncan, D.B. 1955. Multiple ranges and multiple F. tests. Biometrics, 11:1-24.

8. El-Goorani, M.A. 1973. Current status of the fire blight in Egypt. Plant Dis. Reptr., 57: 646.

9. El-Helaly, A.F., M.K. Abo El-Dahab, and M.A. El-Goorani 1964. The occurrence of the fire blight disease of pear in Egypt. Phytopath. Medit., 3: 156-163.

10. Falkenstein, H., W. Zeller and K. Geider.1989. The 29 kb plasmid, common in strains of Erwinia amylovora, modulates development of fire blight symptoms.J.Gen.Microbiol., 135: 2643-2650.

11. Farag, N.S. 1993. Fire blight of pome fruit : Genuinness and Spuriousness. Acta Phytopathologica et Entomologica Hungarica, 28(2-4): 245-256.

12. Farag,N.S., Faiza.G.Fawzi, F. Bishay, T.A. El-Sharkawy and K.Y.Mickail. 1986. Highlights on pear disorder in Egypt. Acta Phytopathologica et Entomologica Hungarica, 21(1-2):99-108.

13. Koski, R.D. and W.R. Jacobi. 2013. Fire blight, Colorado State University Extension No., 2: 907.

14. Krieg, N. R., P. H. A. Sneath, J. T. Staley and S. T. Williams. 1994. Bergey's Manual of Systematic Bacteriology, 9th Ed., Williams and Wilkins, Baltimore, USA. $391 \mathrm{pp}$.

15. Miller, T. D. and M. N. Schroth. 1972. Monitoring the epiphytic population of Erwinia amylovora on pear with a selective medium. Phytopathology, 62: 1175 1182. 
16. Paulin, J.P. and G. Lachaud.1984. Comparison of the Efficiency of Some Chemicals in Preventing Fire Blight Blossom Infections. Acta Horticulturae, 151: 209-214.

17. Paulus, A.O. 1983. Report to Agriculture Development Systems Project, EgyptUSAID. California Univ., Davis, California 95616.June3, 1983.

18. Saied, I.A. and S.A. El-Shall. 1987. Comparison of "Le Conte" pear budded on four rootstocks. J. Agric. Sci. Mansoura Univ., 12(4):1310-1313.

19. Shoeib, Alia.A., N.A. Ashmawy, S.M. Hammed and E.E. Hafez. 2017. Molecular and biological identification of Erwinia amylovora Egyptian isolates compared with other German strains. J. Plant Physiol. Pathol., 5:1-7.

20. Tawfik, A.E., A.F. Abd El-Rahman, E.M. Hussein, and N.Y. Abd El-Ghafar.2006. The status of fire blight on pear in Egypt. Acta Hortic., 704: 387-392.

21. Van der Zwet,T. 1983. Survey of the presence of fire blight in Egypt. U.S. Dept. Agric., Agric. Res. Service, Northeastern region. Travel Rept., May 24-June 4.

22. Van der Zwet, T. 1994. The various means of dissemination of the fire blight bacterium Erwinia amylovora. Bulletin OEPP/EPPO Bulletin., 24: 209-214.

23. Van der Zwet,T. and S.V. Beer.1995. Fire blight -its nature, prevention and control. A practical Guide to Integrated Disease Management.US Department of Agriculture. Agriculture Information Bulletin No.631. Washington DC.

24. Van der Zwet,T. and H.L. Keil .1979. Fire blight. In: Bacterial disease of rosaceous plants. Handbook No., 510, US Department of Agriculture, Government Printing Office, Washington, D.C. 200pp.

25. Westwood, M. N. 1978. Fruit and nut species. In: Temperate-Zone Pomology, M. N. Westwood (ed) Chapt. 3, W. H. Freeman and Co., San Francisco CA, pp. 4176. 


\section{اللفحة النارية بالكمثرى في مصر : خلفية زمنية ونتائج جديدة}

\section{نجلاء موسى بلابل ، نبيل صبحى فرج ، طه أحمد الثرقاوى و فاتن سيد منصور}

$$
\text { معهد بحوث آمراض النباتات - مركز البحوث الزراعبة - جيزة - مصر }
$$

كانت اصابة الكمثرى بمرض اللفحة النارية فى مصر محل نقاش وجدال لفترة طويلة وهذا

بسبب عدم مو اعمة المناخ الجاف لوبائية هذا المرض ـ أجرى هذا العمل كمحاولة لتوضيح سبب هذا الارتباك وتفسير ا لبعض جو انب هذه النتاقضات.

كثف التفتيش الحقلى في البساتين عن وجود حروق و اضحة على أوراق بعض الاتشجار ، دون انتشارلهذه الظاهرة في كثير من الظروف. أختلف علماء آمراض النبات في العديد من المعاهد

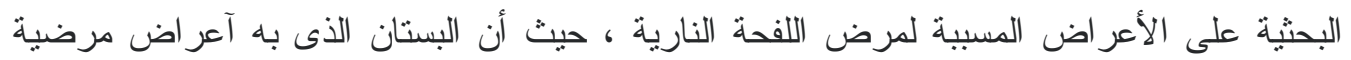

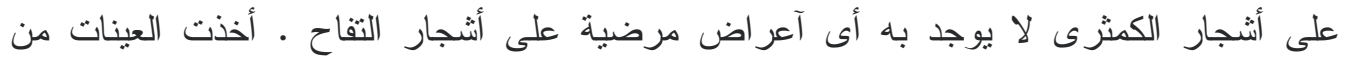

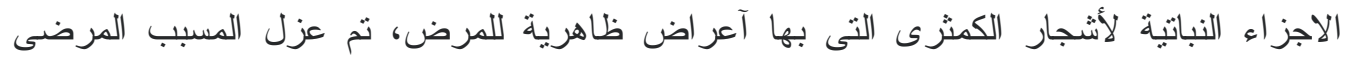

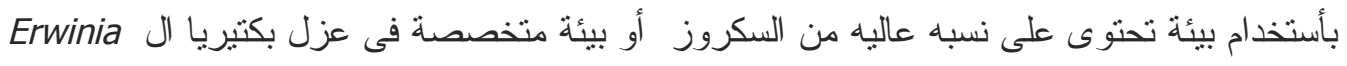
amylovora و الجزيئية عن وجود أي تباين واضح بين العزلات المعزولة من الأجزاء النباتية المختلفة لأشجار

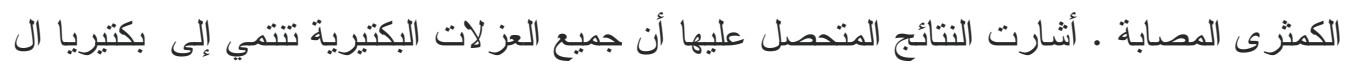
Erwinia amylovora من جذوع الأشجار أكثرحدة مرضية من العزلات المعزولة من الأجزاء النباتية الأخرى. تمت لأت

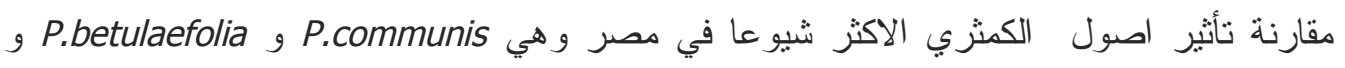
P.calleryana

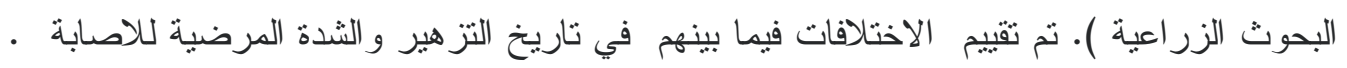

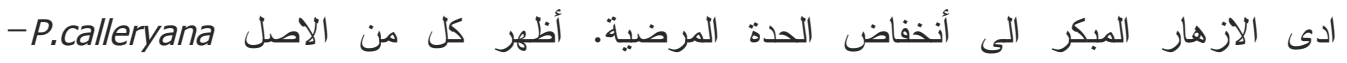
P.betulaefolia الاصابة. ادى التأخر الملحوظ في عملية التزهير للاصل P.communis لنهاية شهر مارس إلى زيلى زيادة شدة الحدة المرضية ، وزيادة أعداد البكتيريا نظرا لتوافه لفر درجة الحرارة الملائمة وزيادة نشاط

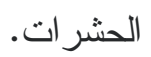

أوضحت النتائج أهمية الدراسة الجيدة لتأثنر اصول الكمثرى على احداثها للمرض . كذلك

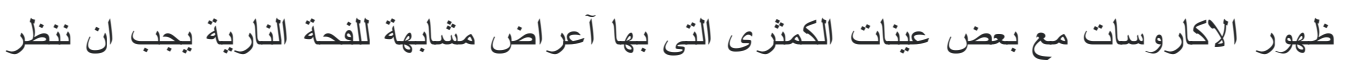
اليها بجدية لمعرفة الدور الذى تلعبه هذه الأفه، مما قد يساهم في تفسير سبب التباين و الملاحظات

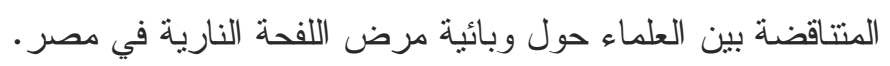


